Eleventh Floor, Menzies Building

Monash University, Wellington Road

CLAYTON Vic 3800 AUSTRALIA

Telephone:

(03) 9905 2398, (03) 99055112

Fax:

(03) 99052426

e-mail:

Internet home page: from overseas:

61399052398 or

61399055112

61399052426

impact@buseco.monash.edu.au http//www.monash.edu.au/policy/

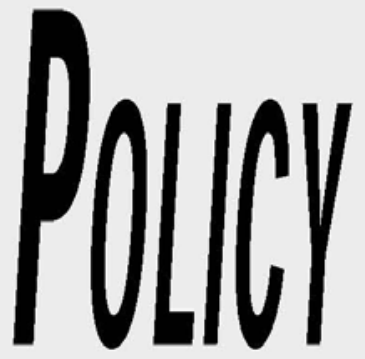

Assessment of the Regional Economic Impacts of Catastrophic Events: CGE analysis of resource loss and behavioral effects of a RDD attack scenario

\author{
by \\ J.A. GIESECKE \\ Centre of Policy Studies \\ Monash University \\ W.J. BURNS \\ Decision Research \\ A. BARRETT \\ E. BAYRAK \\ A.ROSE \\ CREATE \\ University of Southern California \\ and \\ M.SUHER \\ Brown University
}

General Paper No. G-194 January 2010 



\title{
Assessment of the Regional Economic Impacts of Catastrophic Events: CGE analysis of resource loss and behavioral effects of a RDD attack scenario
}

\author{
J.A. Giesecke ${ }^{1}$, W.J. Burns ${ }^{2}$, A. Barrett ${ }^{3}$, E. Bayrak ${ }^{4}$, A. Rose ${ }^{5}$, and M. Suher ${ }^{6}$
}

\begin{abstract}
Using a large-scale CGE model, we investigate the short-run and long-run regional economic consequences of a catastrophic event - attack via radiological dispersal device (RDD) - centered on the downtown Los Angeles area. We distinguish two main routes via which such a catastrophic event might affect regional economic activity: (i) reduction in effective resource supply (the resource loss effect) and (ii) shifts in the perceptions of economic agents (the behavioral effect). Broadly, the resource loss effect relates to the physical destructiveness of the event, while the behavioral effect relates to changes in fear and risk perception on the part of firms, households and government. Both affect the size of the regional economy. RDD detonation (Dirty Bomb) causes little direct capital damage and few casualties, but generates substantial short-run resource loss via business interruption. Changes in fear and risk perception increase the supply cost of resources to the affected region, while simultaneously reducing demand for goods produced in the region. In both the short-run and long-run in the affected region, households may require higher wages to work, investors may require higher returns to invest, and economic agents may switch their preferences away from goods produced. We show that because perception effects may have lingering long-term deleterious impacts on both the supplycost of resources to a region and willingness to pay for regional output, they have the potential to generate changes in real regional GDP that are much greater than those generated by the resource loss effect. Implications for policy that might mitigate these effects are discussed.
\end{abstract}

JEL Classification: H56, R13, C68, D58

Key words: RDD, economic impact, terrorism, risk perception

\section{ACKNOWLEDGEMENTS}

This research was supported by the United States Department of Homeland Security through the National Center for Risk and Economic Analysis of Terrorism Events (CREATE) under grant number 2007-ST-061000001. This research was also supported by the National Science Foundation under grant numbers SES0728934 and SES-0901036. Any opinions, findings and conclusions or recommendations in this document are those of the authors and do not necessarily reflect views of the US Department of Homeland Security and the National Science Foundation. 
1. James A. Giesecke, Centre of Policy Studies, Monash University, Melbourne, Australia.

e-mail: james.giesecke@buseco.monash.edu.au

2. William J. Burns, Decision Research, Eugene, Oregon, U.S.A.

e-mail: william_burns@sbcglobal.net

3. Anthony Barrett, Center for Risk and Economic Analysis of Terrorism Events, University of Southern California, Los Angeles, U.S.A.

e-mail: ambarret@sppd.usc.edu

4. Ergin Bayrak, Center for Risk and Economic Analysis of Terrorism Events, University of Southern California, Los Angeles, U.S.A.

e-mail: ebayrak@usc.edu

5. Adam Rose, Center for Risk and Economic Analysis of Terrorism Events, University of Southern California, Los Angeles, U.S.A.

e-mail: adamzros@sppd.usc.edu

6. Michael Suher, Brown University, Providence, U.S.A.

e-mail: michael.suher@gmail.com 


\section{CONTENTS}

1. INTRODUCTION 1

2. DETONATION OF A RADIOLOGICAL DISPERSAL DEVICE (RDD) 5

3. ORANI-LA: A LARGE-SCALE MODEL OF THE

LA-COUNTY ECONOMY 6

3.1 Overview of the structure of ORANI-LA 6

3.2 Short-run and long-run closures of the ORANI-LA model 7

4. SIMULATION DESIGN 9

4.1 Resource loss effects 9

$\begin{array}{llr}4.2 & \text { Behavioral effects } & 10\end{array}$

$\begin{array}{lll}\text { 5. RESULTS } & 13\end{array}$

$\begin{array}{lll}5.1 & \text { Short-run consequences of RDD attack } & 13\end{array}$

5.1.1 Deaths, injuries and capital damage $\quad 14$

$\begin{array}{ll}\text { 5.1.2 Business interruption } & 15\end{array}$

5.1.3 Short-run behavioral effects $\quad 17$

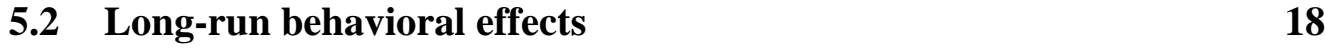

5.2.1 Increase in required rates of return on capital 19

5.2.2 Decrease in willingness to pay for commodities produced in Los Angeles County 20

5.2.3 Increase in required wage in Los Angeles County 21

5.3 Comparison of Effects 22

6. CONCLUSIONS 25

$\begin{array}{lr}\text { REFERENCES } & 28\end{array}$ 


\section{LIST OF FIGURES AND TABLES}

Figure 1 Section of Los Angeles central business district closed for radiological decontamination

Figure 2 Stylised paths for stigma and real regional GDP impacts

Table 1 Regional macroeconomic variables: RDD scenario, event year, percentage change relative to basecase

Table 2 Output by sector: RDD scenario, event year, percentage change relative to basecase

Table 3 Regional macroeconomic variables: RDD scenario, long-run, percentage change relative to basecase

Table 4 Output by sector: RDD scenario, long-run, percentage change relative to basecase

Table 5 Summary comparison of real GRP outcomes 


\section{INTRODUCTION}

Public officials, business leaders, and health care providers are now routinely advised to prepare for the impacts a major disaster or an epidemic might have on their community. Following the events of September 11, Hurricane Katrina, the London subway/bus bombings and most recently worry of a pandemic flu, individuals and organizations have become more aware of their vulnerability to explosions (bombing of buildings, tunnels and bridges), biological agents (flu, Anthrax), radiation releases (“dirty bombs,” attacks on nuclear reactors) and natural disasters. To be sure, there is a clear need to provide researchers and practitioners with a better understanding of how a community is likely to prepare for and respond to calamities of this kind (Lasker, 2004). A critical aspect of this preparation involves understanding how the public perceives different threats and anticipating how people are likely to react during a crisis. This is important because responses by the public may exacerbate the negative economic consequences of disasters.

Beginning in the 1970s, psychologists began to study how people perceived the risks associated with a wide variety of hazards. These investigations showed that perceptions of risk were largely driven by two factors: uncertainty and dread (Fischhoff et al., 1978; Fischhoff et al., 1981). Hazards whose dangers the public thought to be poorly understood, even by experts, were considered highly uncertain. Hazards whose dangers were thought to be potentially catastrophic and difficult to control were considered highly dreaded. Technologies such as nuclear power generated high perceptions of risk because they were both uncertain and dreaded. Natural disasters, such as hurricanes, were better understood, and protective actions more widely accepted; hence they caused less concern.

Researchers have also observed that some mishaps lead to social, political or economic consequences that go far beyond the direct harm they caused. Slovic (1987) has postulated that certain events lead to such ripple effects because they signal some increased future risk. The accident at Three Mile Island for example, signaled to the public that nuclear power was unsafe and potentially catastrophic. Seeking to explain how an event's risk signal might lead to ripple effects Kasperson et al. (1988) proposed 
the social amplification of risk framework. The core idea behind this framework is that an accident, natural disaster or act of terrorism, will interact with psychological, institutional, and cultural processes in ways that may amplify (or attenuate) community response to the event. This theory contends that the effects of an accident or act of terrorism can extend well beyond the direct damages to victims, property, or environment and may result in momentous indirect impacts. When such events occur, information flows through various channels to the public and its many cultural groups. This information is interpreted largely on the basis of its interaction with the above processes. This interaction, in turn, triggers risk-related behavior. Such behavior, together with the influence of the media and special interest groups, generates secondary social and economic consequences that eventually call for additional institutional responses and protective actions (Burns et al., 1993; Burns and Slovic, 2007).

Burns and Slovic (2007, forthcoming) sought to understand how event characteristics might play a role in the amplification of risk process. To do this they created four hypothetical scenarios: propane explosion, flu outbreak, bomb blast and anthrax release. These scenarios varied in terms of the domain (terrorism, no terrorism), mechanism (infectious disease, explosion), security (negligence, no negligence), victim (tourist, government official) and number of fatalities (none, few, many). They reasoned that events involving terrorism, infectious disease, negligent security and tourists would generate more feelings of uncertainty and lack of control. These feelings would in turn markedly increase perceptions of risk because these they would signal increased future threat. It was also predicted that in comparison with terrorism or infectious disease the impact of fatalities would be marginal. This was indeed what was found. Terrorism loomed large in people's perceptions. Fear of terrorism was followed by concern with the mechanism involved (infectious disease more than explosions), and security negligence. Though who the victim was should be irrelevant, tourists generated more concern than government officials. As predicted, the number of casualties contributed little to people's perception of risk. Burns and Slovic later extended these findings by investigating earthquakes and cyber-terrorism as well. They found that cyber-terrorism and especially anthrax generated considerably more concern than earthquakes. The authors concluded 
that terrorism presents a unique policy challenge for community leaders because terrorist acts possess such high risk signal value.

In this paper, we focus on the short-run and long-run regional economic consequences of a Dirty Bomb scenario. In the Burns and Slovic framework, a Dirty Bomb event is likely to have characteristics of low perceived control and high uncertainty, thus generating high perceptions of risk and fear. Hence, we think investigating a Dirty Bomb is interesting because, while it is unlikely to kill many people or do much property damage, it most probably would cause massive disruption from both the standpoints of ordinary business interruption and public perception reactions. Such public alarm could happen because terrorism and the effects of radiation are very difficult to comprehend and communicate. People would be at a loss as to how best to protect themselves thus increasing fear and perceptions of risk. Community leaders may find it exceedingly challenging to persuade residents to return to work in the affected areas despite assurances from experts regarding safety. Consumption of goods originating near the blast site may for a time decline as consumers wrestle with worries of contamination. Investors may shy away due to concerns of long-run lingering contamination, a repeat attack, or concern for the stigma associated with the site. In brief, fear may prove pivotal in determining the short and long term effects from a RDD event.

We argue that there are two main routes via which catastrophic events affect regional economic activity: (i) reduction in effective resource supply (the resource loss effect) and (ii) shifts in the perceptions of economic agents (the behavioral effect). Broadly, the resource loss effect relates to the physical destructiveness of the event, while the behavioral effect relates to changes in fear and risk perception on the part of firms, households and government. Both affect the size of the regional economy. The event we investigate causes deaths and injuries, and destroys or impairs physical capital. These shocks represent a reduction in effective resource supply to the regional economy, directly reducing real regional GDP. We conjecture that long-run behavioral effects may generate regional economic damage additional to these short-run resource loss effects. Changes in fear and risk perception increase the supply cost of resources to the affected 
region, while simultaneously reducing demand for goods produced in the region. In both the short-run and long-run, households may require higher wages to work in the affected region, investors may require higher returns to invest in the affected region, and economic agents may switch their preferences away from goods produced in the affected region. These effects, arising from changes in fear and risk perception, have the potential to cause a significant contraction in the long-run size of the affected region. This is particularly likely under a dirty bomb scenario. We show that because perception effects may have lingering long-term deleterious impacts on both the supply-cost of resources to a region and willingness to pay for regional output, they have the potential to generate changes in real regional GDP that are greater than those generated by the resource loss effect of the event in question.

We use a large-scale regional computable general equilibrium (CGE) model to impose neoclassical economic formalism on our research problem. Our choice of a CGE model as analysis tool is motivated by two features of such models. First, the marriage of detailed data and economic theory within CGE models allows them to be used to analyze economic shocks that are very rare by nature. The catastrophic event modeled in this paper is of this kind. As Dixon and Parmenter (1996: 7) note, use of econometrics in such circumstances may be frustrated by the absence of historically equivalent shocks within the relevant time series data. Second, CGE models emphasize detailed modeling of economic structure. As we show in Section 4, their rich treatment of the structure of both supply and demand sides of the economy facilitate detailed modeling of the resource loss and behavioral impacts of catastrophic events.

Very few studies to date have quantified the economic consequences of altered perceptions following a terrorist attack. Gordon et al. (2007) estimated the "fear factor" associated with a nearly two year decline in airline travel and related tourism in the U.S. following 9/11 as nearly $\$ 400$ billion in lost direct and indirect gross output (approximately $\$ 240$ billion in GDP). Rose et al. (2009), adjusting for the fact that the air travel industry was already in decline due to a pre-9/11 recession found the general equilibrium impact of this fear factor to be around $\$ 100$ billion. Still this accounted for 
more than $80 \%$ of the economic losses they estimated from the terrorist attacks on the World Trade Center. ${ }^{1}$ Gordon et al. used an input-output model with some ad hoc adjustments for substitutes for air travel. Rose et al. used a CGE model with endogenous substitution and various general equilibrium adjustments. In contrast, the methodology presented below is the first to provide a comprehensive and systematic framework for analyzing the economic impacts of extreme behavioral responses to terrorism or any other disaster.

The remainder of this paper is structured as follows. In Section 2, we describe our RDD scenario. Section 3 provides an overview of our CGE model, ORANI-LA. Section 4 discusses how we translate the RDD scenario described in Section 2 into a set of modelcompatible shocks. Section 5 describes the short-run and long-run economic impact on the LA County economy of our hypothetical RDD scenario. Section 6 concludes the paper.

\section{DETONATION OF A RADIOLOGICAL DISPERSAL DEVICE (RDD)}

Gordon et al. (2005) and Pan (2009) indicated that RDD attack scenarios could cause significant economic impact. Our RDD attack scenario is based on DHS' National Planning Scenario 11, "Radiological Attack - Radiological Dispersal Devices” (DHS 2005). In this scenario, the attacker uses a combination of explosives and radiological material (cesium-137) to create an RDD. The explosions cause 180 fatalities and 270 serious injuries. Radiological contamination covers approximately 36 city blocks. 20,000 potential radiological victims in the area require some level of decontamination and medical treatment. Radiological material settling on streets, buildings and other outdoor and indoor surfaces cause authorities to close the area until they can complete enough decontamination and remediation to sufficiently reduce public health risks. Using the DHS scenario as a template, we choose a similarly-sized downtown Los Angeles region as the site for the hypothetical RDD attack: zip code 90071. Figure 1 shows this region (denoted by cross-hatching) and surrounding parts of Los Angeles. 
Official decisions on when to reopen an area after radiological contamination may not be simply dictated by existing safety standards (Eraker 2004; Elcock, Klemic and Taboas 2004; Gordon et al., 2005). A variety of radiological decontamination and remediation techniques might be employed (Volchek et al., 2006), which could result in a range of public access closure times (see, for example, Gordon et al., 2005). Decisions on cleanup options may involve tradeoffs between public safety levels and the costs and economic impacts of decontamination. With business interruption a likely significant cost of RDD attack, we discussed our scenario with Los Angeles public officials, to understand their assessment of the range of cleanup options. The option with lowest disruption time might be simply to use fire hoses to wash down the area, sweeping radiological material into sewers. This option might require subsequent decontamination of sewers, a cost that would need to be compared with the benefits of swift reopening of the downtown area. However, even rapid-decontamination methods may expedite only partial access to the downtown area, since it may be time consuming to decontaminate the interiors of buildings that suffer radiological particle infiltration. Lengthy disruption times would arise if public health officials viewed the extent of contamination to be such that street and building surfaces, or even entire structures, required removal or replacement. Our discussions with Los Angeles public officials indicated that the decision of when to open an area to the public would take into account both the desires of local businesses (who might press for rapid reopening, to minimize business impacts) and the concerns of the public (who desire not only access but also assurances of safety, while possibly also skeptical of official safety proclamations). To reflect a medium-cost cleanup effort, in Section 4 we model a 30 day shutdown of zip code 90071.

\section{ORANI-LA: A LARGE-SCALE MODEL OF THE LA-COUNTY ECONOMY}

\subsection{Overview of the structure of ORANI-LA}

ORANI-LA is an LA-County implementation of the single U.S. region model ORANI-R, documented in Giesecke (2009). As detailed in that paper, ORANI-R is a single-region sub-national variant of the well-known single country models ORANI-G (Horridge 2003) and ORANI (Dixon et al., 1982). The model is implemented using IMPLAN data for LA- 
County (Minnesota IMPLAN Group 1997) and relevant parameter values from the largescale CGE model of the U.S. economy, USAGE ${ }^{2}$. We provide an overview of ORANILA below ${ }^{3}$.

ORANI-LA is a single-region comparative-static computable general equilibrium model of the LA County economy. The model features detailed sectoral disaggregation, modeling both production and capital formation for 436 sectors, and commodity- and agent-specific demands for 19 margin commodities. Familiar neoclassical assumptions govern the behavior of the model's economic agents. Decision-making by firms and households is governed by optimizing behavior. Each representative industry is assumed to minimize costs subject to constant returns to scale production technologies and given input prices. Household commodity demands are modeled via a representative utilitymaximizing household. Units of new industry-specific capital are assumed to be cost minimizing combinations of commodities sourced from the local region, the rest of the U.S. and overseas. Imperfect substitutability between local, rest-of-U.S. and foreign varieties of each commodity are modeled via $\mathrm{CRESH}^{4}$ aggregation functions. Interregional and foreign export demands for local commodities are modeled via commodityand destination-specific constant elasticity export demand schedules. The model recognizes the consumption of commodities by state and federal government. A variety of direct and indirect taxation instruments are identified. Commodity markets are assumed to clear and to be competitive. Purchasers' prices differ from basic prices by the value of indirect taxes and margin services. The model is solved using the GEMPACK economic modeling software (Harrison and Pearson, 1996).

\subsection{Short-run and long-run closures of the ORANI-LA model}

In Section 5 we report short-run and long-run consequences of the RDD scenario described in Section 2. We discuss here our variable closure choices which, taken together, specify economic environments describing short-run and long-run timeframes.

The main defining characteristic of our short-run labour market closure is exogeneity of the regional population. This largely determines regional employment. However, we 
allow for small short-run movements in the regional participation rate, employment rate, and hours worked per worker, in response to movements in the regional real consumer wage. This allows the short-run employment response to differ from short-run settings for regional population. Under our short-run labour market setting, regional labour market pressures are mainly reflected in changes in the regional real wage, with no change in regional population, and only small changes in regional employment.

Like our short-run labour market closure, in the long-run we also allow the regional participation rate, employment rate, and hours worked per worker to be weakly positively related to the regional real consumer wage. The main defining characteristic of our longrun labour market closure is endogeneity of regional population, which is modelled as a strong positive function of the regional real wage. Under our long-run labour market setting, regional labour market pressure is mainly reflected in changes in regional population (and thus employment) with little change in the regional real wage.

In both the short-run and long-run, household consumption spending is assumed to be a fixed proportion of household income. This implicitly means the household savings rate is exogenous. A potential behavioral effect that we have not modeled in this paper is a short-run rise in precautionary savings. Hence, the household savings rate is exogenous and unshocked.

In the short-run, industry-specific capital stocks are exogenous, with industry-specific rates of return on capital adjusting to clear industry-specific capital markets. In the longrun, rates of return on industry-specific capital are exogenous, with industry-specific capital stocks endogenous. Long-run industry-specific investment is determined via an assumption of exogeneity in industry-specific gross capital growth rates.

In the short-run, regional and federal government real public consumption spending are exogenous. In the long-run, the ratio of regional and federal government real public consumption spending to real regional private consumption spending is exogenous. 


\section{SIMULATION DESIGN}

\subsection{Resource loss effects}

We estimate the direct resource loss effects of the RDD scenario at:

1. Casualties: \$26.2 million of lost labour input.

2. Capital damage: None.

3. Business interruption: $\$ 1.4$ billion of lost output.

Our estimate of lost labour input via casualties is built upon detailed assumptions about the distribution of the seriousness of injuries, the proportion of the directly affected population that is employed, the occupational distribution of downtown employment, and average wage rates by occupation. However, abstracting from the occupational detail underlying our calculations, our estimate of \$26.2 million can be understood from the following approximation:

(1) Casualty cost $\approx S E M P *[D+M I *(N M I / 365)+S I *(N S I / 365)] * W A G E \approx \$ 26.2 m$.

where:

SEMP, the proportion of dead and injured that are employed, is 0.8 ;

$\mathrm{D}$, the number killed by the attack, is 180 ;

MI, the number of minor injuries, is 20,000;

NMI, the number of effective work days missed by those with minor injuries, is 7;

SI, the number of serious injuries, is 270 ;

NSI, the number of effective work days missed by those with serious injuries, is 90 ;

WAGE, the average wage of those directly affected by the attack, is $\$ 51,911$ per annum.

Via (1), we see that direct resource loss from deaths is approximately $\$ 7.5$ million, and the direct resource loss from injuries is approximately $\$ 18.7$ million. We model the direct impact of deaths as reduction in regional population sufficient to withdraw \$7.5 million 
of labour from the Los Angeles County economy. We model lost labour input from injury as a decrease in regional labour productivity.

We assume that capital damage from the RDD attack will be negligible compared with other impacts. As such, we set capital damage at zero for our RDD scenario. Capital in the contaminated area is simply "off-limits" during the disruption period.

We base our estimate of the value of business interruption on an estimate of the value of gross output in the affected region, and an assumption of the number of days over which this output will be disrupted. We estimate GDP of zip code 90071 at approximately $\$ 9.8$ billion. ${ }^{5}$ This represents about 2 per cent of LA County GDP, the region for which we estimate economy-wide impacts. We estimate the value of gross output in 90071 at approximately $\$ 16.8$ billion. $^{6}$ As discussed in Section 2, where we describe our Dirty Bomb scenario, we assume that decontamination of 90071 will result in 30 days worth of foregone output via business interruption. This corresponds to $\$ 1.4$ billion of lost output. We model business interruption as a decline in all-input-using technical efficiency calibrated to reduce output for a given level of inputs by $\$ 1.4$ billion.

\subsection{Behavioral effects}

We evaluate the short-run and long-run regional economic consequences of three behavioral effects: a rise in regional wage premium, a rise in regional required rate of return, and fall in willingness to pay for regional exports. We outline below our assumptions for the values of these shocks.

Leeth and Ruser (2003) find compensating wage premiums ranging from 0.5 per cent to 1.4 per cent for fatal and non-fatal injury at mean risk levels across all U.S. industries other than agriculture and mining. For illustrative purposes, we assume workers in the region directly affected by the RDD require a 0.25 per cent compensating wage premium. This is half of the lower range of compensating wage premiums found by Leeth and Ruser (2003). The region directly affected by the RDD represents 2 per cent of Los 
Angeles County economic activity. Hence, in the ORANI-LA model, we implement a +0.005 per cent increase in required wages in the Los Angeles County region.

We infer changes in required rates of return from estimates of the property price impacts of disease outbreaks and proximity to hazardous waste sites. Lucas (2004) found a shortrun 15 per cent drop in home sale prices following an unanticipated outbreak of pediatric leukemia not linked to a specific source. Ihlanfeldt and Taylor (2004) examine the commercial property market, finding a 36 per cent drop in urban commercial property prices arising from proximity to small-scale hazardous urban waste sites. Greenstone and Gallagher (2008) report lower property price impacts of hazardous waste proximity. Their study of Superfund sites estimates 0.7 per cent to 4.7 per cent home price appreciation following site clean-up, although they are unable to reject that the actual price impact is zero. With property price impact estimates ranging from 0 per cent to 36 per cent, we choose 15 per cent as a rough mid-point of this range to guide our estimate of the short- and medium-run rate of return consequences of the RDD event. We note that this number is close to that found by Lucas (2004). With the leukemia hazard studied in Lucas (2004) appearing suddenly, and the actual risk posed to people's health ambiguous, this example has characteristics that most resemble our RDD scenario.

Following Menzies et al. (2009), we estimate the implied movement in required rates of return implicit in property price movements via Tobin's Q, defined as the ratio of an asset's market value to its replacement cost:

(1) $\quad \mathrm{TQ}_{\mathrm{j}}=\mathrm{MV}_{\mathrm{j}} / \mathrm{RV}_{\mathrm{j}}$

where

$\mathrm{TQ}_{\mathrm{j}} \quad$ is Tobin's Q for industry $j$;

$\mathrm{MV}_{\mathrm{j}}$ is the market value of industry $j$ 's assets; and

$\mathrm{RV}_{\mathrm{j}} \quad$ is the replacement value of industry $j$ 's assets. 
Assuming that the market value of the industry's capital is the present value of future income flows, then:

(2) $\quad \mathrm{MV}_{\mathrm{j}}=P_{K, j}\left[\left(1-D_{j}\right) /\left(R R+D_{j}\right)\right]$

where

$P_{K, j} \quad$ is the rental price of a unit of capital in industry $j$;

$D_{j} \quad$ is the depreciation rate on industry $j$ 's capital; and

$R R \quad$ is the real discount rate.

In ORANI-LA, the gross rate of return on industry $j$ 's capital $\left(\mathrm{GROR}_{\mathrm{j}}\right)$ is defined as:

(3) $\quad \mathrm{GROR}_{\mathrm{j}}=P_{K, j} / R V_{j}$

Substituting (1) and (2) into (3):

(4) $\quad \mathrm{GROR}_{\mathrm{j}}=\mathrm{TQ}_{\mathrm{j}}\left[\left(\mathrm{RR}+\mathrm{D}_{\mathrm{j}}\right) /\left(1-\mathrm{D}_{\mathrm{j}}\right)\right]$

A plausible value for $\left(R R+D_{j}\right) /\left(1-D_{j}\right)$ is around 0.13 , with $R R=0.05$ and $D=0.07$. Hence,

(5) $\mathrm{dGROR}_{\mathrm{j}} \approx 0.13 * \mathrm{dTQ}_{\mathrm{j}}$

Tobin's Q is usually around 1.0 - 1.5. If we set the initial level of TQ at 1.25 , then our RDD-induced 15 per cent reduction in asset values is a change in TQ of -0.19. Via (5), this implies a fall in rates of return of -0.024 per cent. Assuming an initial gross rate of return of around 0.12, this implies a percentage fall in rates of return of 20.2 per cent. At any given level of investment, investors require an increase in expected or required rates of return to compensate for the anticipated decline in rates of return. Hence we implement perceived risk in investment as a 20.2 per cent increase in required gross rates of return in industries in the affected region. 
We rely on the stigma-related literature on changes in willingness to pay to inform our shocks to foreign and interstate export demands for goods produced in the affected region. Hayes et al. (1995) conducted an experiment to determine willingness to pay to reduce the risk of food-borne illness in food to a 1 in 100 million chance. They found a willingness to pay of $15 \%-30 \%$, suggesting a discount of $13 \%-23 \%$ for the price of more risky food. Bostedt (2001) found a 54 per cent drop in the price of Swedish reindeer meat in the year of the Chernobyl incident, despite government action to inspect and remove contaminated meat. Hulktrantz and Olsson (1997) investigated the impact of the Chernobyl event and determined that stigma from Chernobyl radiation that reached Sweden caused foreign tourism to fall by 25 per cent. We note that this does not imply a large decrease in willingness to pay on the part of tourists. Assuming an export demand elasticity of around 6, it suggests a willingness to pay reduction of around 4 per cent. Hence, the stigma-related literature finds reductions in willingness to pay ranging from around 4 per cent to 54 per cent. For our simulations, we impose a 25 per cent reduction in foreign and interstate willingness to pay for certain commodities produced in the affected region. We confine the set of commodities that are subject to stigma-related reductions in willingness to pay to agricultural goods, food products, retail services, tourism services, and recreational and hospitality services.

\section{RESULTS}

\subsection{Short-run consequences of RDD attack}

As discussed in Section 4, we distinguish four short-run resource loss routes (business interruption, deaths, injuries, and capital damage and destruction) and three behavioral routes (compensating wage premiums, required rates of return, and willingness to pay) via which catastrophic events affect regional economic activity. The individual contributions of each of these seven factors to the total short-run economic impact of the RDD scenario are reported in Tables 1 and 2. 


\subsubsection{Deaths, injuries and capital damage}

In specifying the RDD scenario, we assumed that no significant capital damage or destruction occurs. This accounts for the absence of short-run capital damage effects in Tables 1 and 2 (column 4). Our RDD scenario also assumes few deaths and injuries. The scenario’s 180 deaths represents lost labour input of approximately $\$ 7.5$ million. This is modelled as a reduction in regional population sufficient to withdraw $\$ 7.5$ million of labour from the Los Angeles County economy. However this generates a fall in real GDP of only $\$ 5$ million (row 15 , column 2). This reflects our regional labour market closure. With regional population (and thus employment) falling via RDD-related deaths, the resulting contraction in regional labour supply causes a small rise in the regional real wage (row 12, column 2). The rise in the regional wage induces small increases in the regional participation rate, employment rate and hours worked per worker, thus damping the employment consequences of the decrease in regional population (row 3, column 2). As such, total regional employment falls by less than that given by the number of RDDrelated deaths alone.

Our RDD scenario specifies 270 serious injuries and 20,000 minor injuries, representing approximately \$19 million in lost labour input. We model this as a decrease in regional labour productivity. This decline in labour productivity causes real regional GDP to fall by $\$ 22$ million (row 15, column 3). This is more than the direct lost labour input via productivity decline (\$19 million) because regional employment falls relative to what it would otherwise have been (row 3, column 3). Labour productivity loss generates two countervailing influences on employment. First, for a given level of output, a fall in labour productivity requires employment of persons to rise. Second, a fall in labour productivity generates a rise in per-unit output costs, causing output demand (and thus employment) to fall. In this scenario, the latter effect dominates, generating a small fall in regional employment (row 3, column 3). This decrease in regional labour demand places downward pressure on the regional real wage (row 12, column 3 ). The cost-consequences of the productivity loss are reflected in the rise of the regional GDP deflator (row 13, column 3). This rise in regional costs relative to costs outside the region generates small decreases in regional foreign and interstate exports (rows 7 and 8 respectively). 


\subsubsection{Business interruption}

Business interruption is the main route via which RDD attack affects the regional economy in the short run (column 1). We model business interruption as a decline in allinput-using technical efficiency calibrated to reduce output for a given level of inputs by $\$ 1.4$ billion. Our short-run labour market closure provides for sticky real wages. Hence, with capital stocks unchanged in the short-run (row 2, column 1), the technical efficiency loss is partly borne by a fall in employment (row 3, column 1) and partly by a fall in the real wage (row 15, column 1). The fall in regional employment accounts for why the ultimate real GDP impact ( $\$ 1.9$ billion) exceeds the direct value of lost sales via business interruption ( $\$ 1.4$ billion).

Much of the short-run real GDP loss from business interruption is reflected in a fall in net foreign and interstate exports (rows 7 - 8). This largely reflects our assumption of shortrun exogeneity of real public consumption spending (row 6, column 1). With public consumption spending exogenous, the decrease in real regional GNE (rows $4-6$, and row 11) is less than the fall in real regional GDP (row 1, column 1). This requires net regional exports to fall, which in turn requires a rise in LA County prices relative to prices outside the region. This accounts for the increase in the regional GDP deflator (row 13, column 1). The rise in the regional GDP deflator moves the real regional balance of trade towards deficit via an increase in the cost of LA-County commodities relative to commodities sourced from the rest of the world.

The movement towards regional real balance of trade deficit is largely expressed as declines in exports to the rest of the U.S. (row 7, column 1) and the rest of the world (row 8, column 1). Despite the movement towards regional real balance of trade deficit, overseas imports decline slightly (row 10, column 1). This reflects the importance, as inputs to production, of certain foreign imports for which there are few domestic substitutes. With real GDP lower (row 1, column 1), demand for foreign imports as production inputs declines, relative to what they would otherwise have been. This activity 
effect exceeds the foreign import demand stimulus provided by real regional appreciation (row 13, column 1 ).

The declines in regional and foreign exports cause the LA-County's terms of trade to improve relative to what they would otherwise have been (row 14). Our consumption closure links regional household nominal consumption to regional household nominal income via an exogenous propensity to consume. With the terms of trade higher, this consumption closure allows the fall in real private consumption (row 5) to be less than the fall in real GDP (row 1). The terms of trade increase also damps the investment decline (row 4) relative to the real GDP decline (row 1). With little change in regional employment (row 3) and capital stocks unchanged in the short-run (row 2), the direct effect of business interruption is to lower rates of return and thus real investment (row 4). However, the direct effect of productivity loss on rates of return is ameliorated by the terms of trade gain (row 14). This accounts for why the reduction in real investment is less than the reduction in real GDP.

ORANI-LA models activity in 436 industries. In Table 2, we aggregate output results for these industries to 15 broad sectors. The sectoral impacts of the RDD event arise largely from business interruption (column 1). The sectors most adversely affected by business interruption are finance and insurance (row 9), business services (row 11) and other services (row 14). This reflects the prominence of these industries in the region directly affected by the RDD, zip code 90071. The output declines in health and education (row 12) and arts (row 13) are due to the fall in real private consumption spending (Table 1, row 5). Both agriculture (row 1), and to a lesser degree, manufacturing (row 5) are provided some insulation from the direct and indirect effects of the RDD event via export exposure. For these sectors, lower per-unit production costs, afforded by the reduction in the regional real wage (row 12, Table 1), facilitates a small increase in output via export expansion. This decrease in input costs is less for manufacturing than agriculture. This accounts for why the expansion in manufacturing output is less than the expansion in agricultural output. RDD attack interrupts provision of finance, insurance and business services to all users, including manufacturing. Compared with agriculture, manufacturing 
is more reliant on inputs of these services. Interrupted provision of these services thus has a more adverse impact on manufacturing production costs than agricultural production costs.

\subsubsection{Short-run behavioral effects}

Columns (5) - (7) of Tables 1 and 2 report the short-run (event year) impacts of our three behavioral effects. As we shall see, relative to their long-run effects, the short-run consequences of the behavioral effects are small. This is because regional factor supplies in the short-run are sticky, since capital stocks are fixed, and regional employment is largely determined by our assumption of short-run exogeneity of the region's population.

In Section 4.2, we describe that investors, fearful of the implications of the RDD attack, require a 2.4 percentage point rate of return premium on investment in the area directly affected. This increase in required rates of return causes regional investment to fall (row 4, column 5). This has only a minor effect on short-run aggregate activity (row 1, column 5) for two reasons. First, investment is not a large share of regional activity, representing approximately 10 per cent of LA County's GDP. Second, investment in the sectors directly affected by rising required rates of return (such as finance, insurance, and business services) is relatively import intensive. This accounts for the large falls in imports (rows 9 and 10, column 5) relative to the fall in real GDP (row 1). In the shortrun, the LA County sector most directly affected by the increase in required rates of return is construction (row 4, column 5, Table 2). This reflects lost sales by the construction sector to investment final demand.

As discussed in Section 4.2, we implement export demand reductions arising from stigma effects through a 25 per cent reduction in foreign and interstate willingness to pay for certain sensitive exports, such as food products and tourism services. At the regional macroeconomic level, this fall in willingness to pay is manifested as a fall in the regional terms of trade (row 14, column 6). With capital stocks fixed, and employment sticky, the terms of trade fall is borne in part by a decrease in capital rates of return, and in part by falls in both employment and the real wage. With capital returns lower, so too is short- 
run investment (row 4, column 6). With employment lower, so too is short-run real GDP (row 1, column 6). The decline in the terms of trade causes household real (CPI-deflated) income to fall more than real GDP. This accounts for why the decrease in real private consumption (row 5, column 6) exceeds the decrease in real GDP. Ceteris paribus, the decrease in export volumes implicit in the willingness to pay shocks exceeds the aggregate decrease in export volumes required by our regional macroeconomic closure. This accounts for the decrease in the regional GDP deflator (row 13, column 6). LA County prices must fall slightly, to stimulate other exports. In Table 2, column 6, this accounts for expansion of such trade-exposed sectors as agriculture (row 1) and manufacturing (row 5).

In Section 4.2 we argued that workers will require a small wage premium to induce them to work in the affected region. We implement this as a 0.005 per cent increase in required wages in Los Angeles county as a whole. The actual increase in the short-run real wage (row 12, column 7) is somewhat less, because the increase in required wages causes labour demand to fall (row 3, column 7). The decrease in short-run regional employment causes real regional GDP to fall (row 1, column 7). With regional income lower, so too is household consumption (row 5, column 7). With employment lower, but capital stocks fixed, rates of return on Los Angeles County capital declines. This accounts for the shortrun fall in real investment (row 4, column 7).

\subsection{Long-run behavioral effects}

Tables 3 and 4 report macroeconomic and sectoral consequences of the behavioral shocks discussed in Section 4.2 for a typical year of the long-run. We interpret the long-run as a period sufficiently far in the future that LA County capital stocks and population have had time to adjust to our shocks, but a period not so distant that RDD-related stigma has had time to disappear. This might reflect a period five to ten years after the RDD event. In aggregate, real regional GDP is projected to be lower by $\$ 3.0$ billion in a typical year of the long-run period over which the adverse behavioral shifts persist. At \$2.9 billion (row 15, column 1) the bulk of this damage is due to our assumption of an increase in required rates of return in the region directly affected by the attack. 


\subsubsection{Increase in required rates of return on capital}

The increase in required rates of return represents an increase in the regional cost of capital. In the long-run, this flows into regional production costs. This is expressed as a long-run positive deviation in the regional GDP deflator (row 13, column 1). With regional production costs higher, demand for commodities produced in Los Angeles County falls. This accounts for the long-run negative outcome for real regional GDP (row 1, column 1). With long-run real GDP lower, so too is long-run employment of capital (row 2, column 1) and labour (row 3, column 1). The increase in the long-run supply cost of regional capital explains why the regional capital stock (row 2, column 1) falls by more than regional employment (row 3, column 1).

The decline in the long-run size of the regional economy causes a decrease in regional imports (rows 9 and 10, column 1), since demand for interstate and foreign goods for consumption, investment and production is now lower. With regional imports lower, and our regional macro closure assumptions ensuring that real regional GNE falls by approximately the same amount as real regional GDP, export volumes must fall (rows 7 and 8 , column 1). The fall in regional export volumes accounts for the long-run increase in the regional terms of trade (row 14, column 1).

The increase in the regional terms of trade allows the fall in real regional consumption (rows 5 and 6) to be less than the fall in real regional GDP (row 1). Of the regional demand-side macro aggregates, it is real investment (row 4, column 1) that is most adversely affected by the rise in required rates of return. This reflects our assumption of an exogenous long-run growth path for the regional economy. Given this assumption, with long-run capital stocks lower by approximately 0.7 per cent (row 2, column 1) annual real investment must be lower by approximately the same magnitude (row 4, column 1).

Table 4 reports long-run sectoral impacts. The Los Angeles County sectors most adversely affected by long-run increases in required rates of return are finance and 
insurance (row 9, column 1) and business services (row 11, column 1). This reflects the concentration of these industries in the region directly affected by the attack (zip code 90071). The construction sector is also among the sectors most adversely affected by the rise in required rates of return (row 4 , column 1 ). This reflects the long-run decrease in regional real investment (row 4, column 1, Table 3).

\subsubsection{Decrease in willingness to pay for commodities produced in Los Angeles County}

Column 2 of Tables 3 and 4 reports the long-run macroeconomic and sectoral consequences of our assumed reductions in foreign and interstate willingness to pay for Los Angeles County commodities that are sensitive to RDD-related stigma. In terms of economic activity in zip code 90071, these sectors are, in the main, related to accommodation, recreation and hospitality. This accounts for the relatively large contractions in the output of the arts and other services sectors in Table 4 (rows 13 and 14, column 2).

The reduction in willingness to pay for LA County goods is equivalent to a "leftward" shift in foreign and interstate demands for such goods. This produces a contraction in the size of the long-run LA County economy. Given our assumptions of exogenous rates of return on capital, and highly elastic population movements in response to changes in the regional wage, relative prices in the regional economy have little scope to move in response to the willingness to pay shocks. Hence, the contraction in activity is spread quite uniformly across supply-side and demand-side macro indicators of economic activity (rows $2-10$, column 2). An exception is overseas exports (row 10, column 2), which expand slightly. This reflects our assumption of long-run regional location preference, which we implement via an assumption that long-run regional real wages are weakly positively related to movements in long-run regional employment. The labour market effects of the long-run decrease in demand for LA County goods mostly manifests as a decline in regional employment (row 3, column 2). However, residents with a preference for continued residence in LA County also accept a lower long-run real wage (row 12, column 2). This reduces long-run LA County production costs (row 13, column 2). ORANI-LA models foreign export demands as more elastic than interstate export 
demands. With LA production costs lower, this not only allows foreign export volumes to expand relative to interstate export volumes, it also accounts for the small net expansion in foreign export volumes.

\subsubsection{Increase in required wage in Los Angeles County}

As discussed in Section 4.2, we assume that fear arising from perceptions of radiological contamination cause workers to require a 0.005 per cent wage premium to work in the LA County region. The actual increase in the long-run real regional wage is somewhat less than this, at +0.004 per cent (row 12, column 3). This reflects our assumption of location preference on the part of regional households. The increase in real regional wages causes regional production costs to rise (row 13, column 3), causing a decrease in demand for LA County goods (row 1, column 3). The resulting decrease in regional employment (row 3, column 3) places downward pressure on the real regional wage as households with some preference for residing in LA County accept lower long-run real wages to avoid emigrating.

The decrease in regional real GDP (row 1, column 3) causes regional demand for capital and labour to fall (rows 2 and 3, column 3). The fall in employment is greater than the fall in capital, because the fear-induced wage premium causes the regional wage/rental ratio to rise. With regional GDP lower, so too is regional income. This accounts for the long-run decline in real private consumption spending. Our long-run public consumption closure specifies exogeneity of the ratio of regional public to private consumption. Hence, the decrease in real public consumption (row 6, column 3) is the same as the decrease in real private consumption (row 5, column 3). The long-run decrease in real investment (row 4) is similar to the long-run decrease in the capital stock (row 2) because we assume the regional economy's long-run underlying growth rate is unaffected by the shock. With regional economic activity lower than it would otherwise have been, so too is demand for imports (rows 10 and 11, column 3). With the decline in real regional GNE approximately matching the decrease in real regional GDP, the decline in import volumes is approximately matched by a decline in export volumes (rows 7 and 8 ). The contraction in foreign export volumes exceeds the contraction in interregional export volumes, 
because foreign export demands are modelled as more price elastic than interregional export demands.

\subsection{Comparison of Effects}

The short-run or event-year impacts of our Dirty Bomb scenario arise almost entirely from business interruption. For a 30 day shut-down of the affected area, as simulated in Section 5.1.2, the impact of business interruption on real GDP, via both direct and indirect routes, is $\$ 1.9$ billion. This represents 97 per cent of the total short-run GDP impact of the Dirty Bomb scenario. Relative to business interruption, resource loss and behavioral effects contribute little to short-run regional economic damage. At \$27 million, the resource loss effect comprises only 1.4 per cent of the short-run real GDP impact. Short-run behavioral impacts on economic activity are also small. This is because behavioral effects have limited scope to influence the regional economy's short-run resource endowment. The behavioral effect's impact on real GDP, at \$35 million, constitutes only 1.8 per cent of the Dirty Bomb’s total short-run real GDP impact.

While the impacts of behavioral effects are relatively small in the short-run, as the economy transitions to its long-run equilibrium, behavioral effects come to exert a significant damping effect on regional economic activity. In a typical long-run year, the behavioral effects cause LA County real GDP to be \$3.0 billion lower than it would otherwise have been. That is, the event's adverse effects in a typical year of the long-run could be 50 per cent larger than the event's total impact in the year of the event. The bulk of the long-run reduction in real GDP (at \$2.9 billion) arises from our assumption that investors require a persistent higher rate of return to invest in zip code 90071. The negative impact on real regional GDP arising from this increase in required rates of return is much larger than that arising from our assumption that workers require a higher wage to induce employment in the affected region. This does not reflect any model-specific property relating to movements in the price of capital compared to movements in the price of labour. Rather, our assumed increase in required rates of return simply represents an increase in the long run price of capital that is far larger than our assumed increase in the long-run required real wage. ${ }^{7}$ 
A further comparison of the results in terms of direct and indirect impacts and in terms of resource loss versus behavioral impacts is presented in Table 5. First, in terms of shortrun business interruption effects, we distinguish between the direct (partial equilibrium) impacts from quarantine of the LA financial district, amounting to $\$ 1,400$ million, and the total county-wide general equilibrium impacts of $\$ 1,870$ million (presented in column 1 of Table 1). The implicit LA county-wide multiplier here is 1.34. In contrast, a typical simple input-output Type II multiplier (including both indirect and induced effects) would be around 2.0. Regional CGE multipliers are smaller than their I-O counterparts, because the former arise from models containing resource constraints and priceresponsive behavior. For instance, the adverse regional labor market pressures generated by the RDD attack are expressed in part as a fall in the regional wage, not only a fall in regional employment.

In comparison to business interruption impacts, the short-run resource loss and behavioral effects are small. The former is due to the relatively small number of people killed and injured, and the latter to short-run stickiness in regional factor supplies.

We need also to place the long-run behavioral impacts in perspective. A full treatment in this regard requires a dynamic regional CGE model and an explicit time path describing the peak and decay of behavioral shocks. Nevertheless, results from our comparativestatic model provide a basis for plausible conjectures about the path of long-run impacts. In Table 3, we presented results for a representative long-run year. For argument, we might view these results as representing impacts five years following the event year (Fig. 2). While stigma effects may be longer lasting, it is unlikely that the premia and discount adjustments to behavioral parameters will remain permanently. In Fig. 2, we portray these effects as having largely dissipated ten years after the event. As such, the event's real GDP consequences have also dissipated by year ten. Assuming straight-line paths from the short-run behavioral real GDP loss ( $\$ 35 \mathrm{~m}$.) to the behavioral loss $(\$ 3049 \mathrm{~m}$.) in the long-run peak year (T1) to the behavioral loss $(\$ 0 \mathrm{~m}$.) in the year that fear effects have dissipated (T2) generates a total real GDP loss of $-35 *(1+\mathrm{T} 1)+(-3049--35) *(1+\mathrm{T} 1) / 2$ 
- 3049*(T2-T1-1)/2. In Fig. 2 we describe $\mathrm{T} 1=5$ and $\mathrm{T} 2=10$, generating total behavioral losses to real GDP of $\$ 15,350 \mathrm{~m}$. At a 5 per cent discount rate, the stream of real GDP losses described in Fig. 2 is $\$ 12,100 \mathrm{~m}$.

Some important ratios are presented at the bottom of Table 5, including the implicit BI multiplier discussed above and a comparison of the long-run 1-year to short-run direct BI multiplier of 2.18. In contrast, the ratio of total long-run output impacts to short-run direct BI impacts is 10.96 . This ratio helps make our point that omission of behavioral impacts would potentially grossly underestimate the consequences of a terrorist attack involving a radiological device. The ratio of total behavioral impacts to total short-run ordinary impacts is 8.09 .

One of the implications of this analysis relates to the importance of finding ways to minimize the negative behavioral impacts of a terrorist attack. One strategy is a thorough clean-up of the site and reassurance that there is no lingering radiation. Of course, another is public confidence in preventing another attack. Our parameter estimates for risk premia are based on a combination of these contingencies. If we assume for purpose of illustration that half the increments are due to fear of lingering contamination, we could compare a NPV of $\$ 6,050(=12100 / 2)$ of behavioral output losses with an increase in direct and indirect BI losses for additional quarantine time. One additional month would cost another $\$ 1.9$ billion in BI (in addition to any additional clean-up expenditures) and would only pass the benefit-cost test if it could reduce the behavioral losses by at least 31 percent.

Finally, we note that we have not considered major sources of economic resilience strategies by individual businesses, households, and government agencies that may mute the impacts otherwise predicted by the CGE model (see, e.g., Rose, 2007). A prime candidate would be business relocation. For example, Rose et al. (2009) found that more than 95 percent of the businesses located in the World Trade Center area survived by finding alternative locations, the vast majority in adjacent areas. However, the actual time for most firms in the World Trade Center to fully relocate was 2-4 months. Hence, 
ordinary physical relocation may not be warranted for a 30-day quarantine period alone. However, not all business "relocation” requires a physical move. Work in cyberspace, telecommuting, and shifts to branch offices have significant potential, especially in the financial industry, which dominates our target area. This could reduce the ordinary direct business interruption losses significantly and reduce the pressure for a rapid cleanup. It would also likely reduce the long-run behavioral impacts, though to a much lesser extent.

\section{CONCLUSIONS}

In this paper we evaluate the regional economic consequences of a Dirty Bomb attack centered on the Los Angeles downtown area. We base our estimates of the direct effects of such an attack on an event of magnitude described in DHS' National Planning Scenario 11, "Radiological Attack - Radiological Dispersal Devices” (DHS 2005). We base our estimates of long-run behavioral effects on existing literature on risk-related wage premiums, the property price consequences of proximity to disease outbreaks and hazardous waste sites, and stigma-related falls in consumer demand.

We find that the economic damage wrought by such an event is dominated by the consequences of business interruption in the short-run and behavioral effects in the longrun. While we have not explored policy responses in this paper, the prominence of the business interruption and behavioral effects suggests a strong role for public policy intervention in mitigating both the short-run and long-run economic costs of a Dirty Bomb event. An effective public policy response might minimise the period of business interruption via efficient and expeditious site clean-up, judicious application of environment and planning regulations, and effective communication of the efficacy of the radiological decontamination effort. Conversations with Los Angeles emergency management personnel suggest that immediately following an event of this kind there would be debate about how best to handle the decontamination efforts and to communicate with the public. Resolving any potential conflicts among key stakeholders, in advance of a crisis, could minimize delays and hence reduce business interruption. Similarly, mitigation of long-run behavioral effects, arising as they do from fear and uncertainty, provides significant scope for policy mediation, particularly in the area of 
allaying community concerns about lingering contamination. Trust in community leaders is pivotal to reducing fear and uncertainty amidst a crisis. A thoughtful and wellimplemented communication program concerning the risks of radiation prior to a Dirty Bomb attack would facilitate such trust. These considerations suggest the possibility of a trade-off between the speed (and thus perceived effectiveness) of site clean-up and the magnitude of long-run behavioral effects. In future work, we hope to investigate this trade-off, with a view to informing public decisions about optimal cleanup efforts. Our results also suggest a role for more traditional economic policy instruments. Since the long-run behavioral effects manifest as increases in long-run regional resource supply prices, and decreases in willingness to pay, these effects might be offset by countervailing federal government subsidies, aimed at directly addressing the cost and price handicaps imposed by misplaced fears of radiological contamination. In future work, we hope to explore the cost in federal government revenue of targeted subsidies addressing long-run behavioral effects from catastrophic events.

A catastrophic event such as detonation of a Dirty Bomb potentially opens a number of additional avenues for shocks to the regional economy that we have not explored in this paper. Site clean-up and remediation will likely involve an expansion in short-run public consumption spending. Assuming this short-run spending is financed by debt or federal government transfers, such spending would have a short-run stimulatory effect on regional economic activity, thus acting to ameliorate the short-run negative effects of business interruption, casualties and behavioral effects. Offsetting this might be a shortrun decrease in private consumption spending, as fearful households increase precautionary savings. Both these short-run consumption effects open permanent longrun financing effects, which again, we have not modelled in this paper. Regional government public debt, incurred to finance clean-up and remediation, creates a long-run debt financing burden. In terms of our modelling, this could be introduced as a long-run decrease in regional private consumption spending, reflecting tax-financing of the interest on additions to regional government public debt. A short-run (event-year) increase in precautionary savings would be mildly expansionary to long-run real private consumption, since it would produce a small permanent increase in regional household 
net assets. Finally, our results at present do not explore the consequences of movements in capital for regional real consumption. In particular, long-run declines in regional capital stocks imply long-run declines in extra-regional financing of that capital. As such, our long-run results for real private consumption slightly overstate the likely long-run adverse consumption result. At present our paper has focused on regional real GDP impacts as the chief indicator of regional economic damage from catastrophic events. This reflects the focus of policy makers, who typically express their interest in the consequences of economic events in terms of anticipated impacts on real GDP and employment. However, assessment of economic welfare calls for of a focus on real consumption outcomes. In future work we, hope to expand our analysis to take account of the preceding short-run consumption and long-run finance effects, thus allowing our results to encompass a more precise assessment of long-run welfare impacts.

\footnotetext{
${ }^{1}$ The main reason the ordinary business interruption losses were so low was due to "resilience" of the economy. Ninety-five percent of the 1,100 firms that occupied the World Trade Center area, survived by relocating to other sites. Similar relocation could take place in the wake of the RDD attack simulated below, but are not analyzed here.

2 USAGE is a detailed, dynamic CGE model of the U.S. It has been developed at the Centre of Policy Studies, Monash University, in collaboration with the U.S. International Trade Commission. Prominent applications of USAGE by the U.S. International Trade Commission include USITC (2004 and 2007)

3 The reader is referred to Giesecke (2009) for further details.

4 "Constant ratios of elasticities of substitution, homothetic" (Hanoch 1971).

${ }^{5}$ We calculate our estimate of GDP at factor cost for zipcode 90071 as follows. From Bureau of Labour Statistics Quarterly Census of Employment and Wages we obtain VLAB $_{\mathrm{s}}$ the wagebill by sector in zipcode 90071. Next, using Los Angeles County data on wages and capital payments from the ORANI-LA database, we calculate $\Psi_{\mathrm{s}}$, the capital / labour ratio for sector $s$. We calculate GDP for zipcode 90071 as $\Sigma_{\mathrm{s}}\left[\mathrm{VLAB}_{\mathrm{s}}+\Psi_{\mathrm{s}} \mathrm{VLAB}_{\mathrm{s}}\right]$.

${ }^{6}$ We calculate the value of output in zipcode 90071 as follows. Using Los Angeles County data on output and value added by sector from the ORANI-LA database, we calculate $\Xi_{\mathrm{s}}$, output / value-added ratios by sector. Using $\Psi_{\mathrm{s}}$, the capital / labour ratio for sector $s$, and $\mathrm{VLAB}_{\mathrm{s}}$, the wagebill by sector in zipcode 90071 (see footnote 4 above), we calculate the total value of sales in zipcode 90071 as $\Sigma_{\mathrm{s}} \Xi_{\mathrm{s}} * \operatorname{VLAB}_{\mathrm{s}}+\Psi_{\mathrm{s}}$ $\left.\mathrm{VLAB}_{\mathrm{s}}\right]$.

${ }^{7}$ Our assumed increase in required rates of return represents an increase in the long-run rental price of capital of 0.44 per cent. At +0.005 per cent (see Section 4.2), our assumed increase in the required regional real wage is just over one per cent $(=100 * 0.005 / 0.44)$ of the increase in the rental price of capital implicit in our rate of return assumption. This explains why, in Table 3, row 15, the GDP impact of the real wage increase is just over one per cent of the GDP impact of the rate of return increase $(=100 * 41 / 2941)$.
} 


\section{REFERENCES}

Bostedt, G. (2001). Reindeer husbandry, the Swedish market for reindeer meat and the Chernobyl effects. Agricultural Economics. Vol. 26.

Burns, W. J. and P. Slovic (2007). "The Diffusion of Fear: Modeling Community Response to a Terrorist Strike." JDMS: The Journal of Defense Modeling and Simulation: Applications, Methodology, Technology Vol. 4, no. 4, http://www.scs.org/PUBs/jdms/vol4num4/Burns.pdf.

Burns, W.J. et al., (1993). "Incorporating Structural Models into Research on the Social Amplification of Risk: Implications for Theory Construction and Decision Making." Risk Analysis 13 : 611-23.

Burns, W.J. \& Slovic, P. (forthcoming). "Predicting and modeling public response to a terrorist strike” In (Ed.) Paul Slovic The Feeling of Risk: New Directions in the Perception of Risk. London: Earthscan Publishing.

DHS (Department of Homeland Security) (2005). National Planning Scenarios: Executive Summaries, US Department of Homeland Security.

Dixon, P.B., B.R. Parmenter, J. Sutton and D.P. Vincent, (1982). ORANI: A multisectoral model of the Australian economy, North-Holland, Amsterdam.

Dixon, P.B. and B.R. Parmenter. (1996). "Computable general equilibrium modelling for policy analysis for forecasting”. In H.M. Amman, D.A. Kendrick and J. Rust (Eds) Handbook of computational economics, vol. 1, chapter 1. Elsevier, Amsterdam, 1996.

Elcock, D., G. A. Klemic, et al. (2004). Establishing Remediation Levels in Response to a Radiological Dispersal Event (or "Dirty Bomb"). Environmental Science and Technology 38(9) 2505-2512.

Eraker, E. (2004). Cleanup After a Radiological Attack: U.S. Prepares Guidance. The Nonproliferation Review 11(3) 167-185.

Falkenrath, R. A. (2005). Statement of Richard A. Falkenrath, Visiting Fellow, The Brookings Institution, Before the United States Senate Committee on Homeland Security and Governmental Affairs, April 27.

Fischhoff, B., Slovic, P., Lichtenstein, S., Read, S., \& Combs, B. (1978). 'How safe is safe enough? A psychometric study of attitudes towards technological risks and benefits'. Policy Sciences, 9, 127-152.

Fischhoff, B., Slovic, P., Lichtenstein, S, Derby, S. L., \& Keeney, R.L. (1981). Acceptable Risk. New York: Cambridge University Press. 
Gordon, P., J. E. Moore II, et al. (2005). The economic impact of a terrorist attack on the twin ports of Los Angeles-Long Beach. The economic impacts of terrorist attacks. H. W. Richardson, P. Gordon and J. E. Moore II. Northampton, Massachusetts, Edward Elgar: 262-286.

Gordon, P., H. Richardson, J. Moore II, J. Park and S. Kim. (2007). "Economic Impacts of a Terrorist Attack on the U.S. Commercial Aviation System," Risk Analysis 27(3): 505-12.

Greenstone, M. and J. Gallagher. (2008). "Does Hazardous Waste Matter? Evidence from the Housing Market and the Superfund Program." Quarterly Journal of Economics. August 2008.

Giesecke, J.A. (2009) Development of a large-scale single U.S. region CGE model using IMPLAN data: a Los Angeles County example with a productivity shock application. General Working Paper No. G-187, Centre of Policy Studies, Monash University, August 2009.

Hanoch, G. (1971). CRESH Production Functions. Econometrica, vol 39, September, pp. $695-712$.

Harrison, W. J. and K. R. Pearson, (1996). Computing Solutions for Large General Equilibrium Models using Gempack, Computational Economics, vol. 9, 83-127.

Hayes, D., J. Shogren, S. Shin, and J. Kliebenstein. (1995). Valuing Food Safety in Experimental Auction Markets. American Journal of Agricultural Economics, Vol. 77, pp. 40-53.

Horridge, J.M. (2003). ORANI-G: A generic single country computable general equilibrium model. <http://www.monash.edu.au/policy/ftp/oranig/oranig03.zip>

Houghton, B. (2004). Gearing Up and Getting There: Improving Local Response to Chemical Terrorism. Santa Monica, California, Pardee RAND Graduate School.

Hultkrantz, L. and C. Olsson. (1997). Chernobyl Effects on Domestic and Inbound Tourism in Sweden - A Time Series Analysis. Environmental and Resource Economics, Vol. 9 pp. 239-258.

Ihlanfeldt, K. and L. Taylor. (2004). "Externality Effects of Small-Scale Hazardous Waste Sites: Evidence from Urban Commercial Property Markets," Journal of Environmental Economics and Management, vol. 47, pp. 117-139.

Kasperson, R.E. et al., (1988). "The Social Amplification of Risk: A Conceptual Framework.” Risk Analysis 8 (1988): 177-87. 
Lasker, R.D. (2004). Redefining Readiness: Terrorism Planning through the Eyes of the Public: The New York Academy of Medicine, Center for the Advancement of Collaborative Strategies in Health, September.

Leeth, J.D. and J. Ruser. (2003). Compensating Wage Differentials for Fatal and Nonfatal Injury Risk by Gender and Race, Journal of Risk and Uncertainty. vol. 27, no. 3.

Lucas, D. (2004). The Effect of Health Risk on Housing Values: Evidence from a Cancer Cluster. American Economic Review. Vol. 94, No. 5.

Menzies, G., R. Bird, P. Dixon and M. Rimmer. (2009). The economic costs of U.S. stock mispricing. Centre of Policy Studies, Monash University, Melbourne, Australia.

Minnesota IMPLAN Group. (1997). IMPLAN System (19xx/20xx data and software), 1725 Tower Drive west, Suite 140, Stillwater, MN 55082, www.implan.com, 1997.

Pan, Q., H. W. Richardson, et al. (2009). "The Economic Impacts of a Terrorist Attack on the Downtown Los Angeles Financial District." Spatial Economic Analysis, Vol. 4, No. 2, pp. 213-239.

Rose, A., Oladosu, G., Lee, B., and Beeler-Asay, G. (2009). "The Economic Impacts of the 2001 Terrorist Attacks on the World Trade Center: A Computable General Equilibrium Analysis,” Peace Economics, Peace Science, and Public Policy, 15(4), Article 4.

Slovic, P. (1987). “Perception of Risk.” Science 236 (1987): 280-85.

Volchek, K., M. Fingas, et al. (2006). Decontamination in the Event of a Chemical or Radiological Terrorist Attack. In Protection of Civilian Infrastructure from Acts of Terrorism. K. V. Frolov and G. B. Baecher, eds. Dordrecht, Springer: 125-145. 
Figure 1: Section of Los Angeles central business district closed for radiological decontamination

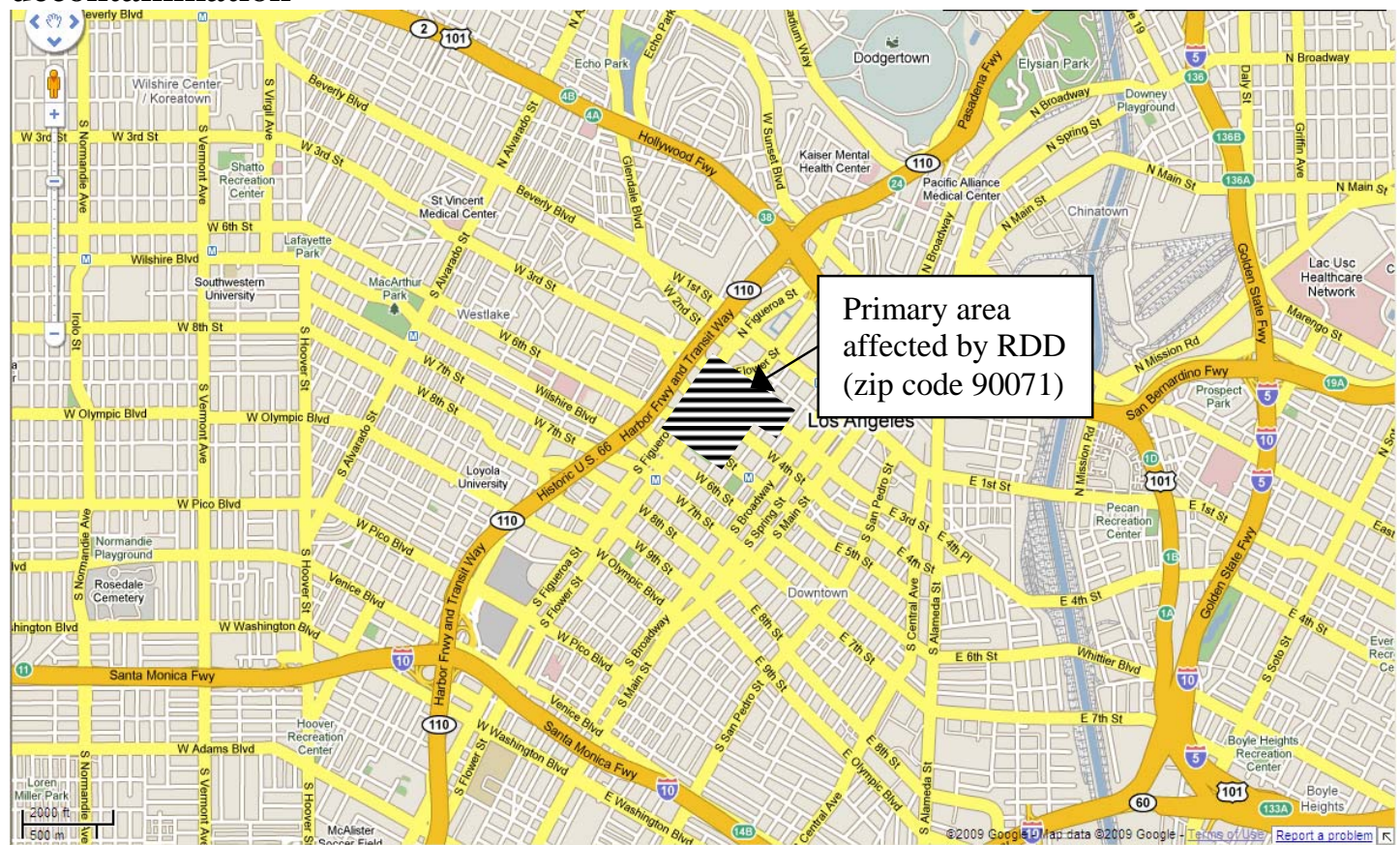

(Map image (C) 2009 Google) 
Figure 2: Stylised paths for stigma and real regional GDP impacts

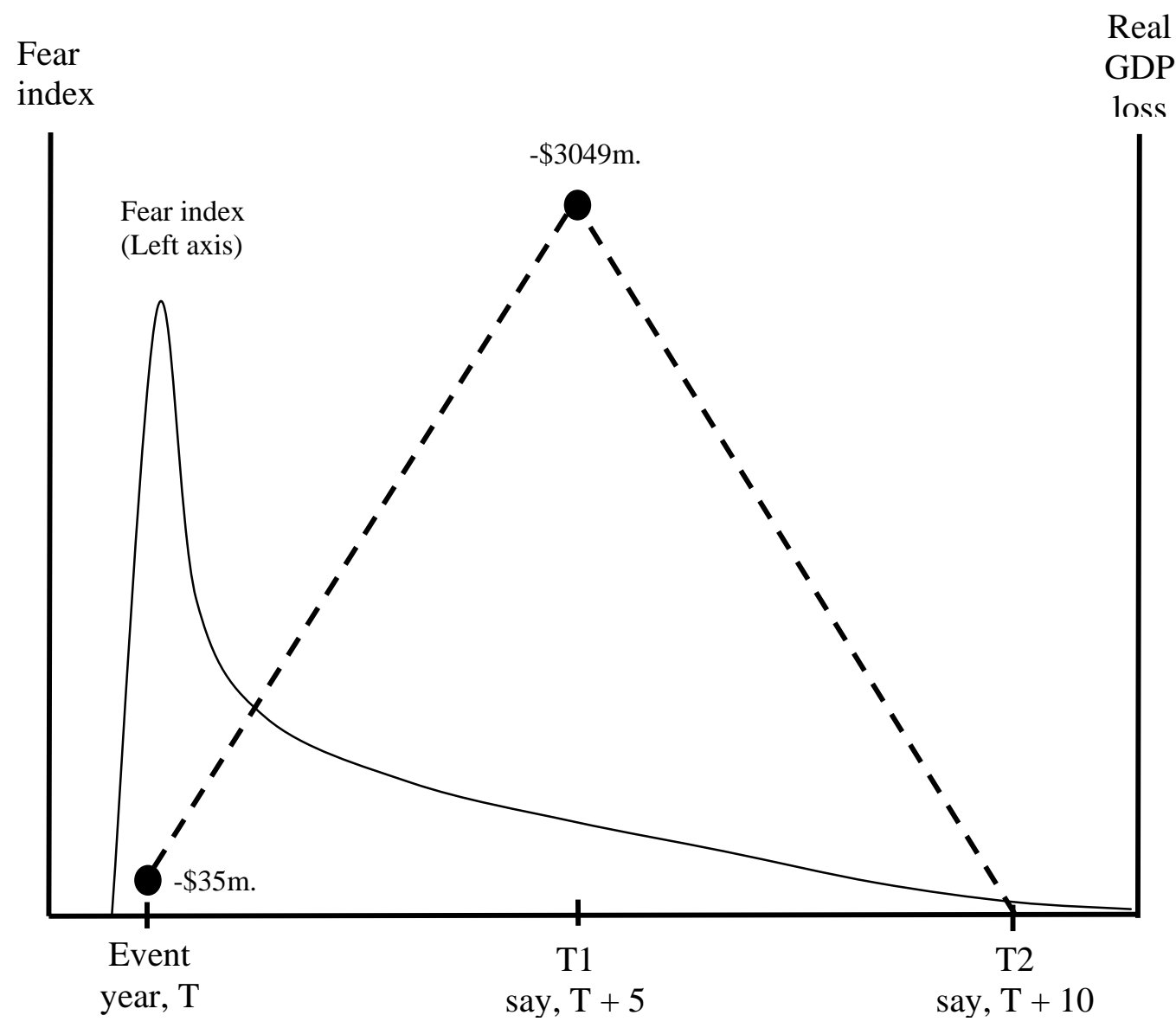


Table 1: Regional macroeconomic variables: RDD scenario, event year, percentage change relative to basecase (unless otherwise specified)

\begin{tabular}{|c|c|c|c|c|c|c|c|c|}
\hline \multirow[b]{2}{*}{ Regional macro variable: } & \multicolumn{4}{|c|}{ Resource loss effects } & \multicolumn{3}{|c|}{ Behavioural effects } & \multirow[b]{2}{*}{ (7) Total } \\
\hline & $\begin{array}{l}\text { (1) Business } \\
\text { interuption }\end{array}$ & (2) Deaths & (3) Injuries & $\begin{array}{r}\text { (4) Capital } \\
\text { damage }\end{array}$ & $\begin{array}{r}(5) \text { Required } \\
\text { rates of return }\end{array}$ & $\begin{array}{r}\text { (6) Willingness } \\
\text { to pay }\end{array}$ & $\begin{array}{l}\text { (7) Wage } \\
\text { premium }\end{array}$ & \\
\hline 1. Real GDP & -0.37 & -0.001 & -0.004 & 0.000 & -0.004 & -0.001 & -0.001 & -0.38 \\
\hline 2. Capital stock & 0.00 & 0.000 & 0.000 & 0.000 & 0.000 & 0.000 & 0.000 & 0.00 \\
\hline 3. Employment & -0.15 & -0.002 & -0.001 & 0.000 & -0.006 & -0.002 & -0.002 & -0.16 \\
\hline 4. Real investment & -0.20 & -0.001 & -0.004 & 0.000 & -0.222 & -0.005 & -0.001 & -0.43 \\
\hline 5. Real private consumption & -0.32 & -0.001 & -0.003 & 0.000 & -0.013 & -0.004 & -0.001 & -0.35 \\
\hline 6. Real public consumption & 0.00 & 0.000 & 0.000 & 0.000 & 0.000 & 0.000 & 0.000 & 0.00 \\
\hline 7. Real interregional exports & -0.20 & -0.001 & -0.003 & 0.000 & 0.017 & -0.007 & -0.001 & -0.19 \\
\hline 8. Real overseas exports & -0.18 & -0.003 & -0.005 & 0.000 & 0.050 & 0.015 & -0.004 & -0.12 \\
\hline 9. Real interregional imports & 0.07 & 0.000 & 0.000 & 0.000 & -0.026 & -0.010 & 0.000 & 0.03 \\
\hline 10. Real overseas imports & -0.11 & -0.001 & -0.002 & 0.000 & -0.025 & -0.003 & -0.001 & -0.14 \\
\hline 11. Real inventories & 0.03 & -0.002 & -0.001 & 0.000 & 0.013 & 0.006 & -0.002 & 0.04 \\
\hline 12. Real wage & -0.15 & 0.002 & -0.001 & 0.000 & -0.006 & -0.002 & 0.003 & -0.16 \\
\hline 13. GDP deflator & 0.02 & 0.001 & 0.001 & 0.000 & -0.022 & -0.010 & 0.001 & 0.00 \\
\hline 14. Terms of trade & 0.08 & 0.001 & 0.001 & 0.000 & -0.009 & -0.006 & 0.001 & 0.06 \\
\hline 15. Real GDP (\$m.) & $-\$ 1,870$ & $-\$ 5$ & $-\$ 22$ & $\$ 0$ & $-\$ 22$ & $-\$ 6$ & $-\$ 7$ & $-\$ 1,932$ \\
\hline
\end{tabular}

Source: Authors' calculations based on ORANI-LA simulations. 
Table 2: Output by sector: RDD scenario, event year, percentage change relative to basecase

\begin{tabular}{|c|c|c|c|c|c|c|c|c|}
\hline \multirow[b]{2}{*}{ Regional industry: } & \multicolumn{4}{|c|}{ Resource loss effects } & \multicolumn{3}{|c|}{ Behavioural effects } & \multirow[b]{2}{*}{ (7) Total } \\
\hline & $\begin{array}{l}\text { (1) Business } \\
\text { interuption }\end{array}$ & (2) Deaths & (3) Injuries & $\begin{array}{r}\text { (4) Capital } \\
\text { damage }\end{array}$ & $\begin{array}{r}(5) \text { Required } \\
\text { rates of return }\end{array}$ & $\begin{array}{r}\text { (6) Willingness } \\
\text { to pay }\end{array}$ & $\begin{array}{l}\text { (7) Wage } \\
\text { premium }\end{array}$ & \\
\hline 1. Agriculture & 0.10 & -0.002 & 0.000 & 0.000 & 0.017 & 0.007 & -0.002 & 0.12 \\
\hline 2. Mining & 0.00 & -0.001 & 0.000 & 0.000 & 0.005 & 0.002 & -0.001 & 0.01 \\
\hline 3. Utilities & -0.04 & 0.000 & -0.001 & 0.000 & -0.001 & -0.001 & -0.001 & -0.04 \\
\hline 4. Construction & -0.12 & -0.001 & -0.002 & 0.000 & -0.096 & -0.004 & -0.001 & -0.23 \\
\hline 5. Manufacturing & 0.04 & -0.002 & -0.001 & 0.000 & 0.013 & 0.006 & -0.003 & 0.06 \\
\hline 6. Trade & -0.11 & -0.001 & -0.002 & 0.000 & -0.030 & -0.001 & -0.001 & -0.14 \\
\hline 7. Transport & 0.02 & -0.002 & -0.001 & 0.000 & 0.002 & 0.005 & -0.002 & 0.02 \\
\hline 8. Information & 0.02 & -0.001 & 0.000 & 0.000 & 0.007 & 0.003 & -0.001 & 0.03 \\
\hline 9. Finance, insurance & -0.89 & -0.001 & -0.014 & 0.000 & 0.004 & 0.002 & -0.001 & -0.90 \\
\hline 10. Dwellings & 0.00 & 0.000 & 0.000 & 0.000 & 0.000 & 0.000 & 0.000 & 0.00 \\
\hline 11. Business services & -0.50 & -0.001 & -0.008 & 0.000 & 0.005 & 0.005 & -0.002 & -0.51 \\
\hline 12. Health \& education & -0.16 & -0.001 & -0.002 & 0.000 & -0.002 & -0.001 & -0.002 & -0.17 \\
\hline 13. Arts & -0.12 & -0.001 & -0.002 & 0.000 & 0.003 & -0.025 & -0.002 & -0.15 \\
\hline 14. Other services & -0.19 & -0.002 & -0.004 & 0.000 & 0.004 & -0.039 & -0.002 & -0.23 \\
\hline 15. Public administration & -0.03 & 0.000 & 0.000 & 0.000 & 0.001 & -0.002 & 0.000 & -0.03 \\
\hline
\end{tabular}

Source: Authors' calculations based on ORANI-LA simulations. 
Table 3: Regional macroeconomic variables: RDD scenario, long-run, percentage change relative

to basecase (unless otherwise specified)

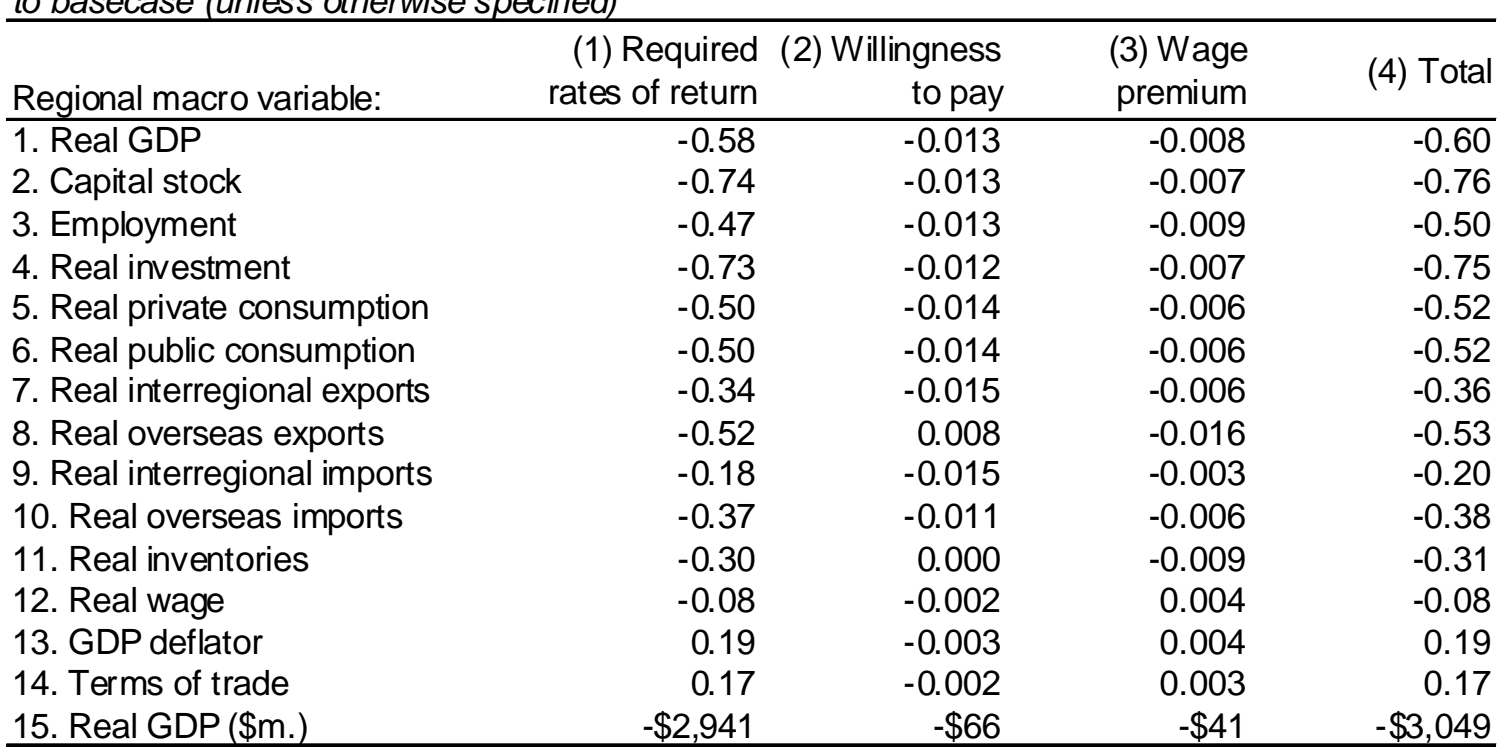

Source: Authors' calculations based on ORANI-LA simulations. 
Table 4: Output by sector: RDD scenario, long-run, percentage change relative to basecase

\begin{tabular}{lrrrr}
\hline Regional industry: & $\begin{array}{r}\text { (1) Required } \\
\text { rates of return }\end{array}$ & $\begin{array}{r}\text { (2) Willingness } \\
\text { to pay }\end{array}$ & $\begin{array}{r}\text { (3) Wage } \\
\text { premium }\end{array}$ & (4) Total \\
\hline 1. Agriculture & -0.27 & 0.00 & -0.01 & -0.28 \\
2. Mining & -0.45 & 0.00 & -0.01 & -0.47 \\
3. Utilities & -0.57 & -0.01 & -0.01 & -0.59 \\
4. Construction & -0.60 & -0.02 & -0.01 & -0.63 \\
5. Manufacturing & -0.29 & 0.00 & -0.01 & -0.30 \\
6. Trade & -0.41 & -0.01 & -0.01 & -0.43 \\
7. Transport & -0.34 & 0.00 & -0.01 & -0.36 \\
8. Information & -0.21 & 0.00 & -0.01 & -0.21 \\
9. Finance, insurance & -1.13 & -0.01 & -0.01 & -1.14 \\
10. Dwellings & -0.53 & -0.01 & -0.01 & -0.55 \\
11. Business services & -0.77 & -0.01 & -0.01 & -0.79 \\
12. Health \& education & -0.49 & -0.01 & -0.01 & -0.51 \\
13. Arts & -0.41 & -0.06 & -0.01 & -0.48 \\
14. Other services & -0.49 & -0.09 & -0.01 & -0.58 \\
15. Public administration & -0.48 & -0.02 & -0.01 & -0.51 \\
\hline
\end{tabular}

Source: Authors' calculations based on ORANI-LA simulations. 
Table 5: Summary comparison of real GRP outcomes

\begin{tabular}{llr}
\hline Impact & Category & Real GRP \\
\hline (1) Short-run & Direct business interruption (BI) \\
(2) Short-run & Indirect business interruption (BI) & $-\$ 1,400$ \\
(3) Short-run & Other resource loss & $-\$ 470$ \\
(4) Short-run & Behavioral & $-\$ 27$ \\
& & $-\$ 35$ \\
(5) Short-run & Total short-run & $-\$ 1,932$ \\
& & \\
(6) Long-run & One-Year Behavioral & $-\$ 3,049$ \\
(7) Long-run & Total Ten-Year Behavioral & $-\$ 15,350$ \\
& & \\
(8) NPV & NPV (at 5\%) of Total Ten-Year Behavioral & $-\$ 12,100$ \\
& & \\
(9) Ratio $=[(1)+(2)] /(1)$ & S-R total BI/S-R Direct BI & 1.34 \\
(10) Ratio $=[(1)+(2)+(3)] /(1)$ & S-R Total/S-R Direct BI & 1.38 \\
(11) Ratio $=(6) /(1)$ & L-R One-Year/S-R Direct BI & 2.18 \\
(12) Ratio $=(7) /(1)$ & Total Ten-Year Behavioral/S-R Direct BI \\
(13) Ratio $=(7) /[(1)+(2)+(3)]$ & Total Ten-Year Behavioral/Ordinary Loss & 10.96 \\
\hline Source: Authors' calculations based on ORANI-LA simulations. & 8.09 \\
\hline
\end{tabular}

Source: Authors' calculations based on ORANI-LA simulations. 